\title{
Sleeping on a tightrope: White-breasted Cormorants Phalacrocorax lucidus and African Darters Anhinga rufa roosting on transmission lines
}

Karis Daniel, Itxaso Quintana and Les G Underhill

\section{biodiversity}

observations

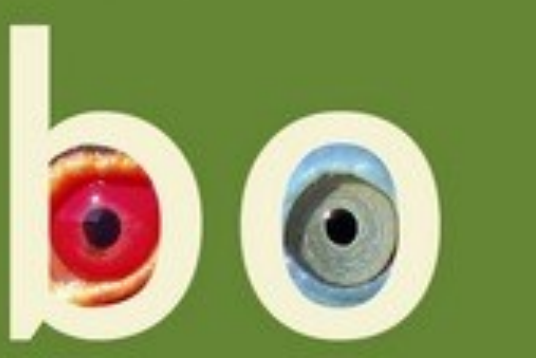

Daniel K, Quintana I, Underhill LG 2020. Sleeping on a tightrope: White-breasted Cormorants Phalacrocorax lucidus and African Darters Anhinga rufa roosting on transmission lines. Biodiversity Observations 11.5: 1-7

Communal roosting, electricity cables, infrastructure roosting, waterbirds, South Africa 


\section{Ornithology}

\section{Sleeping on a tightrope: White-breasted Cormo- rants Phalacrocorax lucidus and African Darters Anhinga rufa roosting on transmission lines}

Karis Daniel, Department of Biological Sciences, University of Cape Town, Rondebosch 7701, South Africa

email: DNLKAR006@myuct.ac.za

Itxaso Quintana, Global Training Programme, University of the Basque Country, Donostia, San Sebastián 20018, Spain, and Biodiversity and Development Institute, Gunners Park, Gunners Circle, Epping, South Africa

Les G Underhill, Animal Demography Unit, Department of Biological Sciences, University of Cape Town, Rondebosch 7701, South Africa, and Biodiversity and Development Institute, Gunners Park, Gunners

Circle, Epping, South Africa

\section{Abstract}

Though recent research has explored the negative impact of human infrastructure on large waterbirds, few studies have examined behavioural byproducts such as roosting or nesting on transmission wires. Here, we document our observation of a joint roost of White-breasted Cormorant Phalacrocorax lucidus and African Darter Anhinga rufa on transmission lines in the Western Cape, South Africa. We highlight current gaps in understanding communal roosting, joint roosts between species, and roosting on infrastructure, and provide recommendations for future directions of study.

Key words: communal roosting, electricity cables, infrastructure roosting, waterbirds, South Africa.

\section{Introduction}

White-breasted Cormorant Phalacrocorax lucidus and African Darter Anhinga rufa are large waterbird species, both widespread across subSaharan Africa and considered Least Concern by the IUCN (IUCN 2020). White-breasted Cormorant is common in salt and freshwater habitats ranging from coastal to wetland and riverine (Chittenden et al. 2016). African Darter is locally common in freshwater bodies and wetlands, preferring open, slow-moving water with vegetated or rocky banks (Chittenden et al. 2016)

Both species are nomadic in response to changing water quality and levels and are somewhat gregarious at breeding and roosting sites, often aggregating in mixed flocks with other large piscivorous birds (Chittenden et al. 2016; Sinclair et al. 2011). Inland, White-breasted Cormorant and African Darter often form mixed breeding colonies, together with Reed Cormorant Microcarbo africanus, African Spoonbill Platalea alba, and herons (Tarboton 1977; Chittenden et al. 2016). Roosting of White-breasted Cormorant and African Darter in natural structures such as trees, bushes or large reedbeds has been previously reported as common (Chittenden et al. 2016).

Volume 1 of the Handbook of the Birds of the World lists four cormorant species (Great Cormorant Phalacrocorax carbo, Brandt's Cormorant $P$. penicillatus, Double-crested Cormorant $P$. auritus and Neotropic Cormorant $P$. brasilianus) as "capable of perching on cables" (del Hoyo et al. 1992, p. 330), however, this statement is made without references. From the context, it is also not clear whether roosting (as opposed to simply perching) on cables was reported. There are few mentions of cormorants roosting on electricity transmission infrastructure (Bartholomew 1943, Brown \& Lawson 1989). Perhaps the bestdocumented incidence stems from the city of Orleans, Massachusetts, in the United States, where guano from a large roost of Double-crested Cormorant on power lines resulted in a court case and the subsequent removal of the infrastructure (Genter 2019). Still, there appear to be no formal and easily accessible accounts of any species of cormorant or darter roosting on transmission lines. 


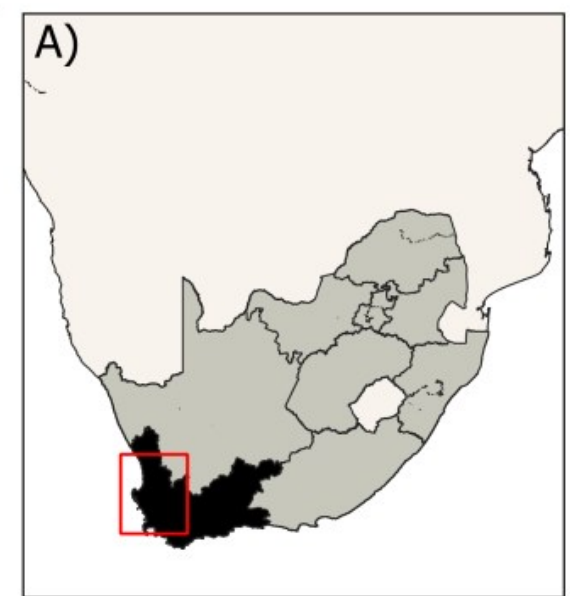

B)

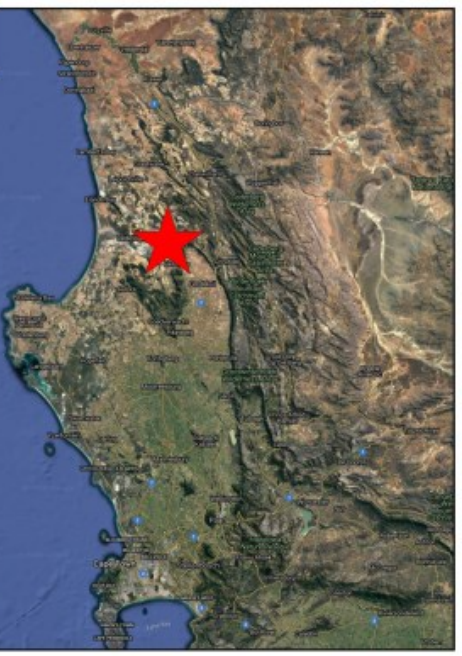

C)
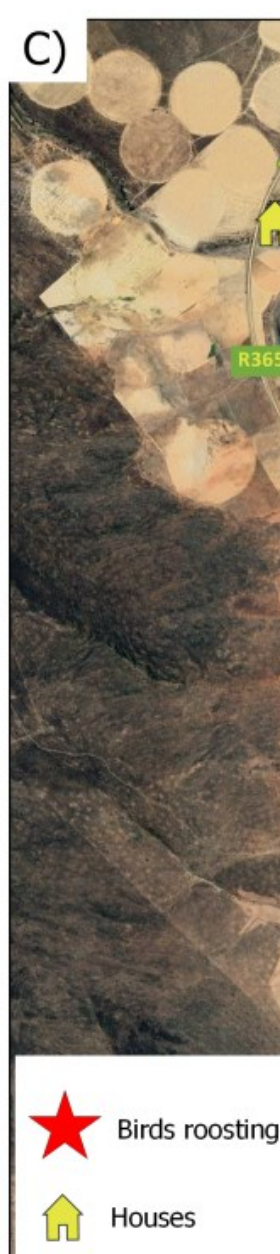

1
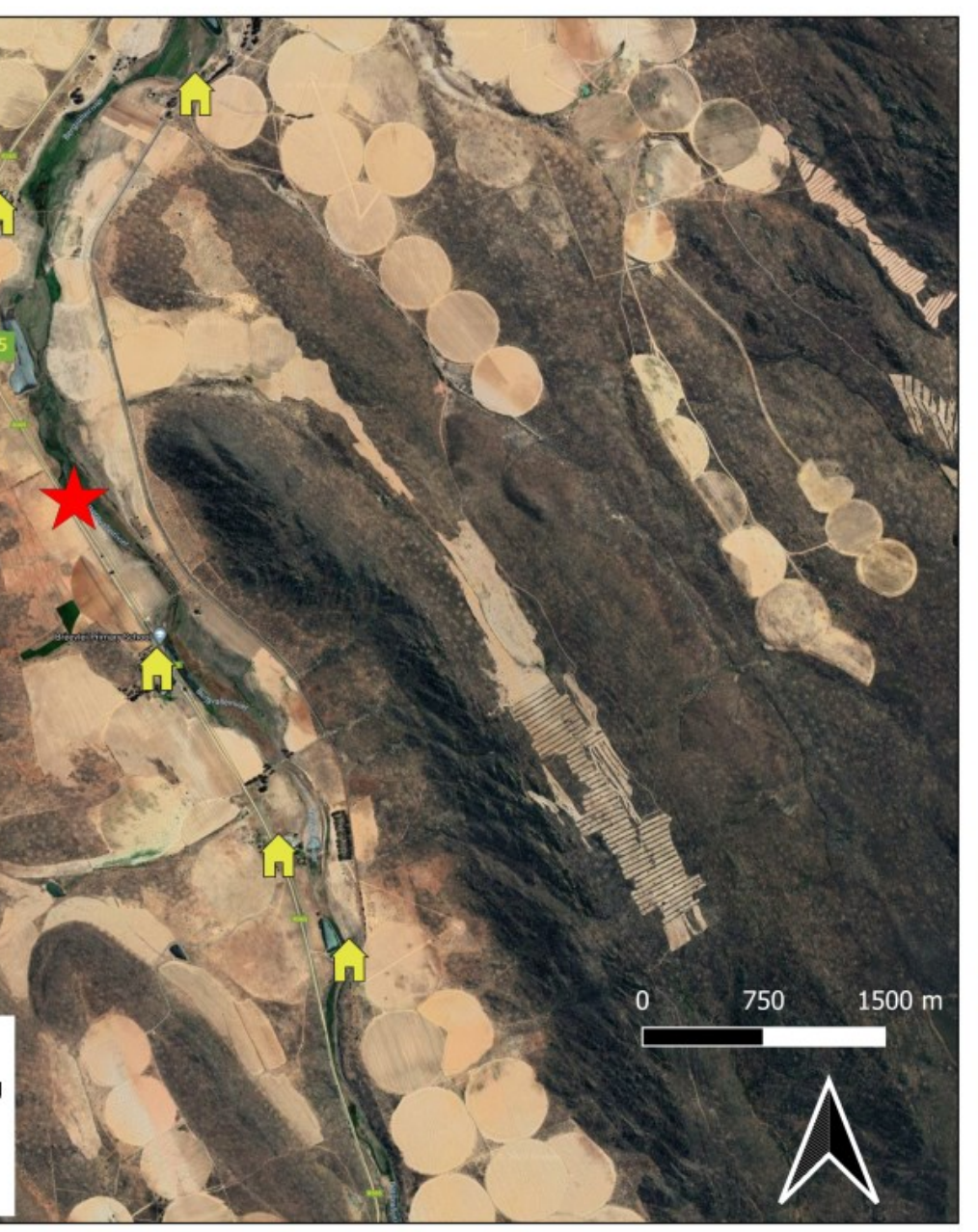

D)

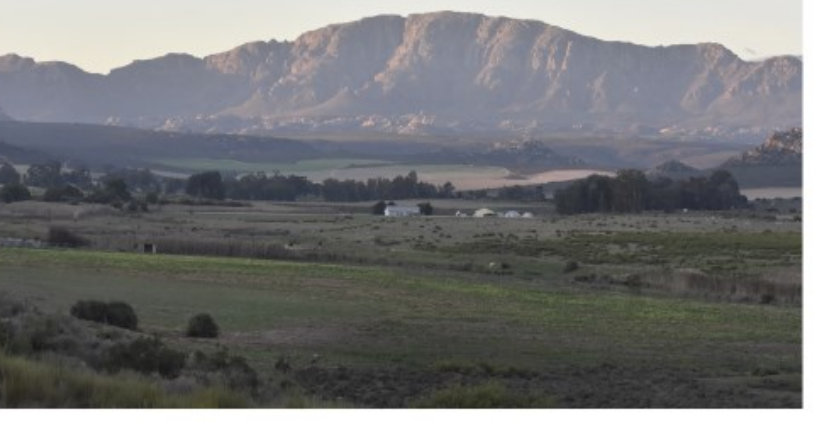

E)

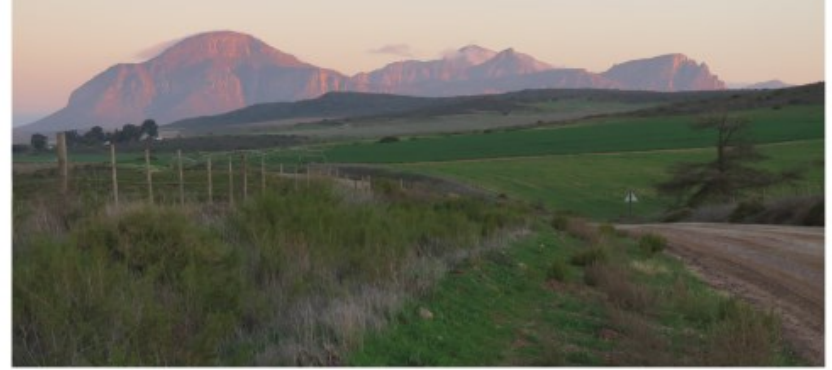

Figure 1. Maps and photos showing location of communal roost. A) Location of Western Cape in South Africa. B) Map showing the location of the roost within the Western Cape; the red star represents the roost location. C) Map of the area where White-breasted Cormorant and African Darter were observed roosting. D and E) Photos showing habitat where roost was observed. Photo credits: Karis Daniel and Itxaso Quintana. 
This note reports an observation of a joint roost of White-breasted Cormorants and African Darters on electricity transmission lines in the Western Cape, South Africa.

\section{Methods}

Over the period 26 to 29 June 2020, we conducted a road trip dedicated to data collection for the Virtual Museum (vmus.adu.org.za), and especially for BirdPix (the section of the Virtual Museum dedicated to the curation of bird distribution data), in the northern arm of the Western Cape. We stopped regularly to photograph birds.

On both 26 and 29 June we travelled along minor roads to the west of the N7, the national road from Cape Town to Namibia. We carried out fieldwork between the ocean and the N7, in the area between Citrusdal in the south and Klawer in the north (Fig. 1).

\section{Results}

On both 26 and 29 June we passed a small farm dam, overgrown with Phragmites reeds, alongside the road numbered R365 and close to the Bergvallei River, near Paleisheuwel. The road served rural communities in a broad valley, and had little traffic (Fig. 1). An $11 \mathrm{kV}$ electricity rural transmission line (see figure 2.14 in Scott 1992) ran along the east side of the road and over the dam.

On 26 June, both White-breasted Cormorants and African Darters were observed on this dam, as well as on numerous other small dams in the valley. No more than two birds were present at each locality.

On 29 June 2020, at 17h45 (dusk), we encountered a mixed flock of these two species gathering to roost on the $11 \mathrm{kV}$ transmission line. The roost was directly above the dam $\left(32.512^{\circ} \mathrm{S}, 18.711^{\circ} \mathrm{E}\right.$; Fig. 1). Surrounding habitat consisted primarily of farmland, with fields used for crops (mainly potatoes) and grazing, and included several farm dams and scrubby natural vegetation (Fig. 1). In total, 34 White-breasted Cormorants and 30 African Darters were seen roosting together on transmission lines (Fig. 2). Numbers reflect our best estimates from photographs; actual totals may have differed slightly because birds continued to fly in and out as we left. The two records are curated in the BirdPix section of the Virtual Museum: White-breasted Cormorant and African Darter.

\section{Discussion}

\section{Choice of roost site}

The valley itself contained large Eucalyptus trees, some within $1 \mathrm{~km}$ of the observed roosting site (Fig. 1). Inland cormorants and darters roost mainly on trees (Doug Harebottle pers. comm) and both Whitebreasted Cormorant and African Darter have also been documented breeding in Eucalyptus (Smith 1974). There is no obvious explanation as to why the birds chose to roost on transmission wires instead of on the available trees. Given the small numbers of birds at each of the farm dams in the valley, a roost of this size must host White-breasted Cormorants and African Darters from a reasonably large surrounding area, with birds dispersing several kilometres during the day to forage. In light of this, the choice of transmission lines remains puzzling. Speculative suggestions include that the birds preferentially roost above water, or, perhaps more intriguingly, transmission lines may be perceived as providing increased protection from predators.

\section{Waterbirds utilizing electricity transmission line infrastructure}

Few studies have described waterbirds utilizing transmission lines, especially for roosting. Bartholomew (1943) described large groups of cormorants roosting on a power line near San Francisco in the USA over 75 years ago; the author then hypothesized that cormorants use power lines when a) no suitable natural roosts are present, and b) power lines are relatively free of human disturbance. Since this publication, however, accounts of waterbirds roosting on transmission lines are anecdotal; the majority of research in this field focuses on negative impacts of infrastructure (i.e. power line collision, electrocution, etc.) rather than adaptive behaviour (Bernardino et al. 2018). An exception is a study by Kucherenko et al. (2014), who documented 86 species using overhead transmission lines in the Crimean Peninsula, 17 of which used the infrastructure for nesting. Among the 86 species were seven waterbirds, including the Great Cormorant, which was once observed perching on a transmission line. 


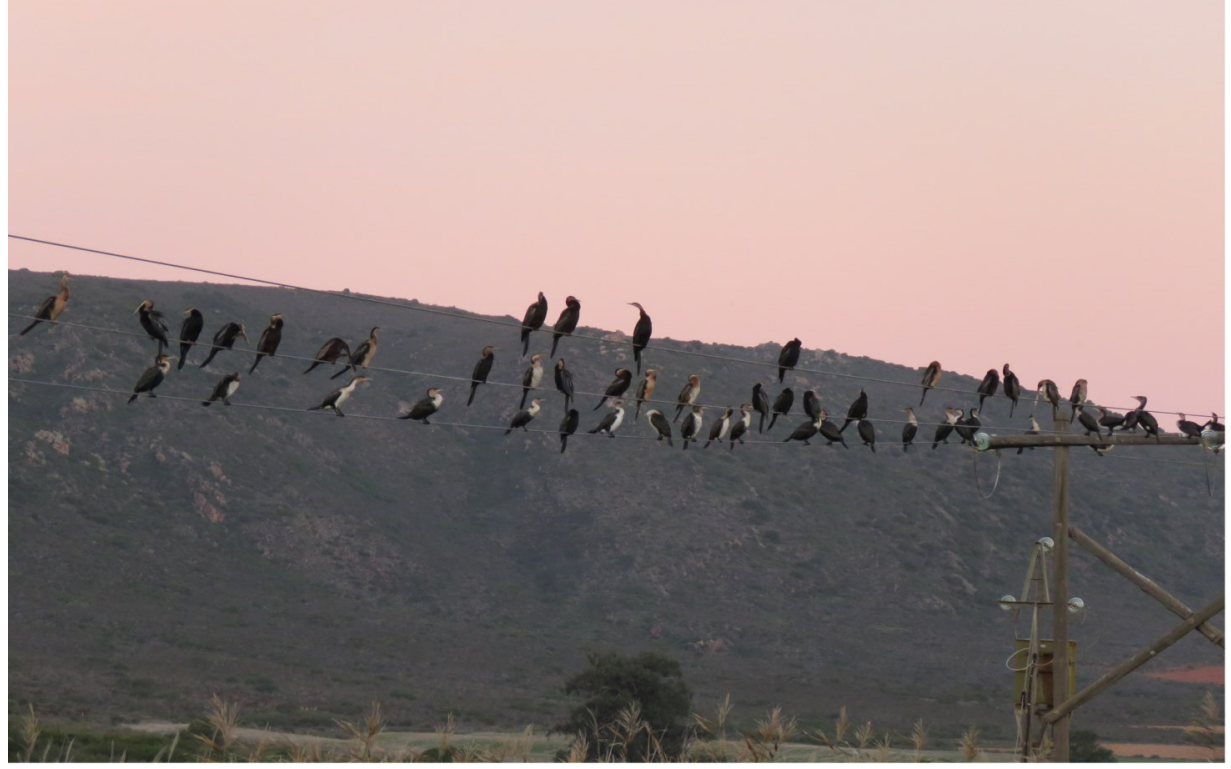

C)

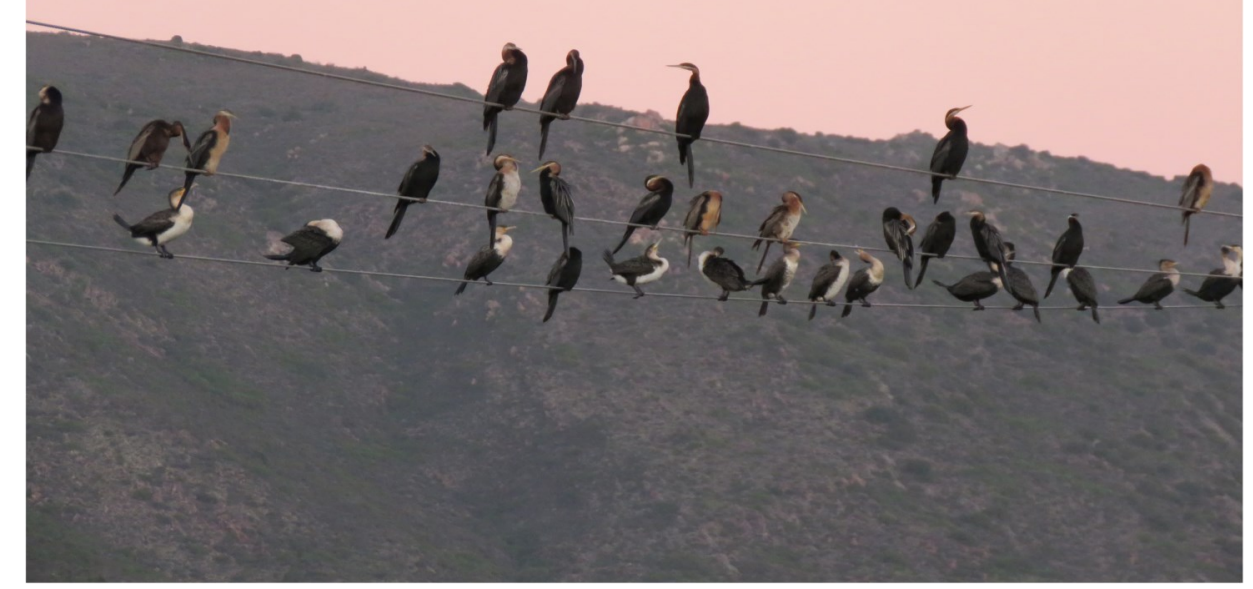

D)
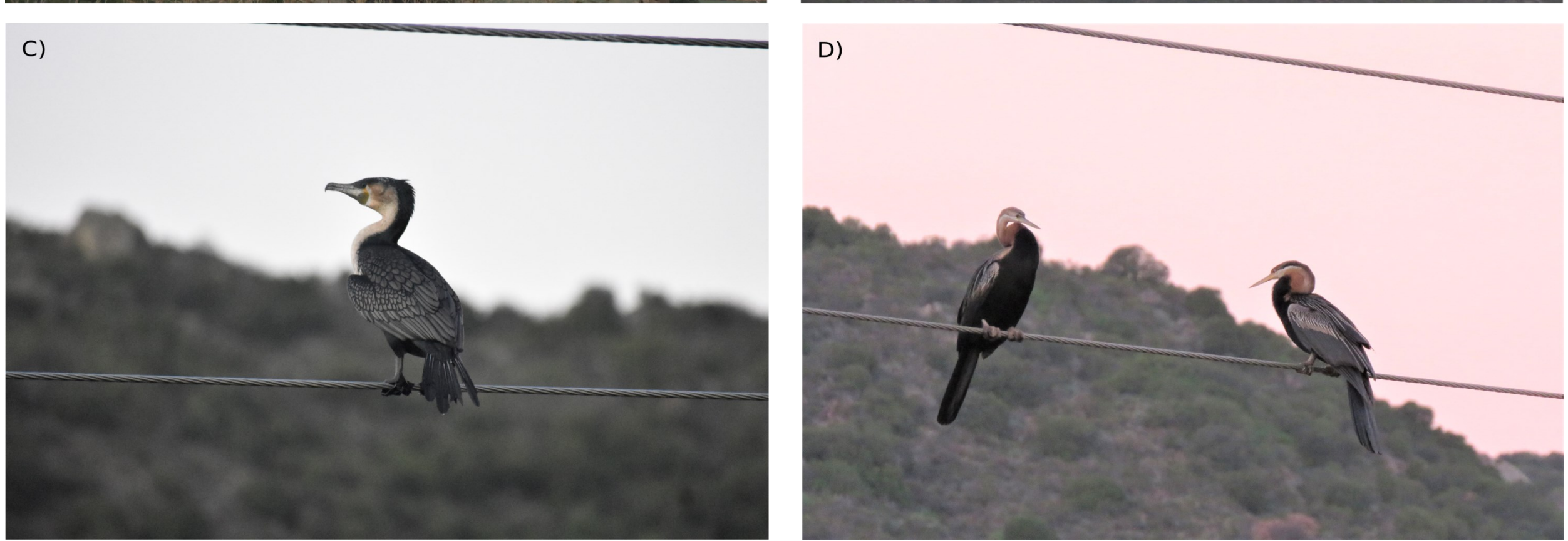

Figure 2. A and B) White-breasted Cormorants Phalacrocorax lucidus and African Darters Anhinga rufa roosting together on transmission lines along the R365, Western Cape. C) White-breasted Cormorant, and D) African Darters. Photo credit: Karis Daniel and Itxaso Quintana. 


\section{Communal roosting}

Our search of the literature also identified a gap in knowledge related to communal roosting. Reasons for this behaviour are poorly understood; three main hypotheses include improved thermoregulation, decreased risk of predation, and increased foraging efficiency (Beauchamp 1999). Siegfried et al. (1975) found that although Cape Cormorants Phalacrocorax capensis roost and forage together, other southern African cormorant species tend to forage solitarily. This potentially rules out foraging efficiency as an explanation for communal roosting in White-breasted Cormorant.

Aside from Beauchamp (1999), we found no studies discussing the significance of joint roosting behaviours between species of large waterbirds. Though joint roosts are mentioned in several publications, they are seldom the subject of research for any bird species. The few formalised accounts include a summary of species composition in communal roosts of Indian birds (Gadgil \& Ali 1975), African Sacred Ibis Threskiornis aethiopicus and Marabou Stork Leptoptilos crumeniferus roosting together in Kenya (Evans et al. 1982), and mixed-species roosts of parrots/parakeets in Costa Rican dry forest (Chapman et al. 1989). This scarcity of information highlights a need for further research into ecological processes underlying the patterns visible in roosting behaviours, as well as a stronger overall understanding of cormorant and darter behavioural ecology.

\section{Conclusions}

Based on our observations and a brief survey of the literature, we recommend further studies investigating 1) novel or adaptive interactions between large waterbirds and human infrastructure, i.e. roosting or nesting on transmission lines; 2) the origin of communal roosting in cormorant and darter species; 2) potential mechanisms driving joint roosting behaviour in both species. Clearer insights in these three areas will deepen our understanding of waterbird behaviour within novel ecosystems, ultimately informing conservation action for these species.

\section{Acknowledgements}

Pavel Tomkovich translated the Russian reference. Doug Harebottle contributed helpful insights about roosting behaviour. Salome Willemse provided logistical support at Botuin, Vanrhynsdorp.

\section{References}

Bartholomew GA 1943. The daily movements of cormorants on San Francisco Bay. Condor 45: 3-18.

Beauchamp G 1999. The evolution of communal roosting in birds: Origin and secondary losses. Behavioral Ecology 10.6: 675-687.

Bernardino J, Bevanger K, Barrientos R, Dwyer JF, Marques AT, Martins RC, Shaw JM, Silva JP, Moreira F 2018. Bird collisions with power lines: State of the art and priority areas for research. Biological Conservation 222: 1-13.

Brown JL, Lawson CJ 1989. Birds and electricity transmission lines in South West Africa/Namibia. Madoqua 16: 59-67.

Chapman CA, Chapman LJ, Lefebvre L 1989. Variability in parrot flock size: possible functions of communal roosts. Condor 91: 842847.

Chittenden H, Davies G, Weiersbye I (eds) 2016. Roberts Bird Guide (2nd ed). John Voelcker Bird Book Fund, Cape Town.

del Hoyo J, Elliott A, Sargatal J (eds) 1992. Handbook of the Birds of the World. Volume 1. Lynx Edicions, Barcelona.

Evans SM, Cantrell MA, Cram A 1982. Patterns of arrival and dispersal from a mixed communal roost of Sacred lbises and Marabou Storks. Ostrich 53: 230-234.

Gadgil M, Ali S 1975. Communal roosting habits of Indian birds. Journal of the Bombay Natural History Society 72: 716-727.

Genter E 2019. Cormorant roost removed over Orleans pond. Cape Cod Times. 7 March 2019. Available online at https:// www.capecodtimes.com/news/20190306/cormorant-roost-removedover-orleans-pond

IUCN 2020. The IUCN Red List of Threatened Species. Version 2020- 
2. Available online at https://www.iucnredlist.org.

Kucherenko VM, Andryushchenko YuO, Popenko I 2014. On the use and avoidance of overhead transmission lines by birds in the Crimea. Branta: Transactions of the Azov-Black Sea Ornithological Station 17: 39-49. [In Russian, with English summary]

Scott RA 1992. Comparison and evaluation of South African poletop designs for $11 \mathrm{kV}$ and $22 \mathrm{kV}$ rural distribution lines. MSc thesis, Department of Electrical and Electronic Engineering, University of Cape

Town. Available online at https://open.uct.ac.za/handle/11427/8353

Siegfried WR, Williams AJ, Frost PGH, Kinahan JB 1975. Plumage and ecology of cormorants. Zoologica Africana 10: 183-192.

Sinclair I, Hockey P, Tarboton W, Ryan P 2011. Sasol Birds of Southern Africa (4th ed.). Penguin Random House, Cape Town.

Smith KD 1974. The utilization of gum trees by birds in Africa. Ibis 116 : 155-164.

Tarboton WA 1977. The status of communal herons, ibis and cormorants on the Witwatersrand. South African Journal of Wildlife Research 7: 19-25.

\section{Editorial acknowledgements}

Robert JM Crawford and Philip A Whittington helped to improve the submitted version.

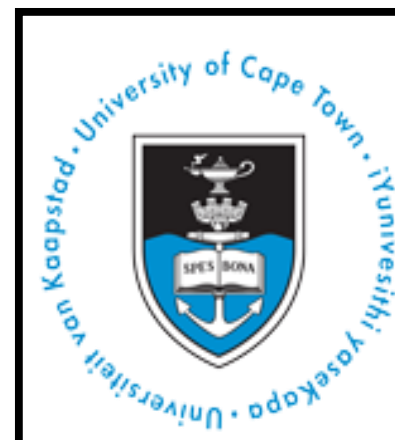

Biodiversity Observations is powered by

Open Journal Systems (OJS) and is hosted by the University of Cape Town Libraries. OJS is an open source software application for managing and publishing scholarly journals. Developed and released by the Public Knowledge Project in 2001, it is the most widely used open source journal publishing

\section{Biodiversity Observations}

The scope of Biodiversity Observations includes papers describing observations about biodiversity in general, including animals, plants, algae and fungi. This includes observations of behaviour, breeding and flowering patterns, distributions and range extensions, foraging, food, movement, measurements, habitat and colouration/plumage variations. Biotic interactions such as pollination, fruit dispersal, herbivory and predation fall within the scope, as well as the use of indigenous and exotic species by humans. Observations of naturalised plants and animals will also be considered. Biodiversity Observations will also publish a variety of other interesting or relevant biodiversity material: reports of projects and conferences, annotated checklists for a site or region, specialist bibliographies, book reviews and any other appropriate material. Further details and guidelines to authors are on the journal website (https://journals.uct.ac.za/index.php/BO/).

ISSN 2219-0341

Editors: PN Laver and LG Underhill

biodiversity observations

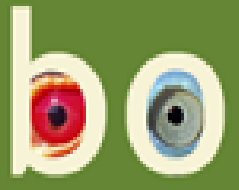

